\title{
PENGARUH GAYA KEPEMIMPINAN DAN BUDAYA ORGANISASI TERHADAP KINERJA PEGAWAI
}

\author{
Suharyanto \\ Program Pasca Sarjana Universitas Narotama Surabaya
}

\begin{abstract}
ABSTRAK
Peningkatan pelayanan mahasiswa sangat terkait dengan gaya kepemimpinan dan budaya organisasi lembaga/instansi terkait, sehingga dapat mewujudkan kinerja yang optimal. Universitas PGRI Adi Buana Surabaya merupakan salah satu universitas swasta yang berupaya memberikan layanannya kepada seluruh akademisi terkait. Secara segnifikan, terdapat pengaruh antara Gaya kepemimpinan Rektor secara parsial terhadap Kinerja Pegawai Universitas PGRI Adi Buana Surabaya. Hal ini dapat diartikan bahwa semakin baik Gaya Kepemimpinan Rektor yang dijalankan, maka kinerja pegawai Universitas PGRI Adibuana Surabaya akan semakin meningkat. Terdapat pula pengaruh signifikan antara Budaya Organisasi secara parsial terhadap Kinerja Pegawai Universitas PGRI Adi Buana Surabaya. Hal ini dapat diartikan bahwa semakin baik Budaya Organisasi yang diterapkan oleh pimpinan dan pegawai, maka kinerja pegawai semakin meningkat.

Kata Kunci : gaya kepemimpinan, kinerja pegawai
\end{abstract}

\section{Pendahuluan}

Dalam suatu organisasi mempunyai tujuan untuk menciptakan suatu produk yaitu dalam bentuk barang atau jasa. Sukanto dan Handoko (2000: 5) menjelaskan bahwa Organisasi adalah perserikatan orang-orang yang masing-masing diberi peranan tertentu dalam suatu sistem kerja dan pembagian kerja dalam mana pekerjaan itu diperinci menjadi tugas-tugas, dibagikan diantara pemegang peranan dan kemudian digabung kedalam berbagai bentuk hasil. Akibat terjadinya interaksi dengan karakteristik masing-masing serta banyak kepentingan, maka membentuk gaya hidup, pola perilaku, dan etika kerja, yang kesemuanya akan mencirikan kondisi suatu organisasi. Setiap individu dalam organisasi tidak lepas dari hakekat nilai-nilai budaya yang dianutnya yang akhirnya akan bersinergi dengan perangkat organisasi, teknologi, sistem, strategi dan gaya hidup kepemimpinan. Pola interaksi sumber daya manusia dalam organisasi harus diseimbangkan dan diselaraskan agar oganisasi dapat tetap eksis.

Universitas Adi Buana Surabaya yang disingkat UNIPA Surabaya merupakan Perguruan Tinggi Swasta di Surabaya dibawah Koordinator Kopertis Wilayah VII Jawa Timur menjadi obyek penelitian ini karena lembaga tersebut bertanggung jawab atas peserta didik (masyarakat) dan para pegawainya. UNIPA Surabaya adalah suatu lembaga yang menghasilkan lulusan di bidang pendidikan dan mampu menghasilkan kader bangsa berperilaku profesional, mampu melakukan riset dan memiliki jiwa kewirausahaan. Peningkatan kinerja pegawai diharapkan akan dapat meningkatkan pelayanan pada masyarakat dalam hal ini mahasiswa. Di sisi lain kemampuan pelayanan terhadap mahasiswa masih jauh dari harapan. Peningkatan pelayanan mahasiswa sangat terkait dengan gaya kepemimpinan dan budaya organisasi lembaga/instansi terkait, sehingga dapat mewujudkan kinerja yang optimal.

\section{Tinjauan Pustaka}

Masalah kepemimpinan muncul sejak manusia menyadari bahwa pentingnya hidup berkelompok, sehingga membutuhkan seseorang atau lebih yang memiliki kelebihan dari pada yang lain, hal ini karena manusia mempunyai keterbatasan dan kelebihan tertentu. Kepemimpinan mengalami pergeseran dari waktu ke waktu dan bersifat kontekstual yang dilatarbelakangi oleh perkembangan sosial, politik dan budaya yang berlaku pada jamannya. Dalam pendekatan situasional disadari bahwa tidak ada satupun gaya kepemimpinan yang terbaik dan berlaku universal untuk segala situasi dan lingkungan.

Hersey \& Balnchard (Pasolong 2010: 50) mengemukakan bahwa gaya kepemimpinan situasional terdiri dari 4 (empat) yaitu:

1. Gaya Instruksi.

Menerapkan kepada bawahan yang memiliki tingkat kematangan yang rendah, dalam hal ini bawahan yang tidak mampu dan tidak mau, sehingga pengawasan yang ketat memiliki tingkat kemungkinan yang efektif yang paling tinggi. Oleh karena itu instruksi pemimpin yang dirujuk karena dicirikan dengan peranan pemimpin yang menginstruksikan bawahan tentang apa, bagaimana dan dimana harus melakukan sesuatu tugas tertentu. 
2. Gaya Konsultas

Menerapkan kepada bawahan yang memiliki tingkat kematangan rendah ke sedang dalam hal ini bawahan yang tidak mampu tetapi berkeinginan untuk memikul tanggung jawab. Oleh karena itu selain pengarahan, dukungan juga komunikasi 2 (dua) arah lebih sering dilakukan, namum demikian pengendalian dan keputusan tetap pada pimpinan.

3. Gaya Partisipasi.

Menerapkan kepada bawahan yang memiliki tingkat kematangan dari sedang ke tinggi dalam hal ini bawahan memiliki kemampuan tetapi tidak memiliki kemauan untuk melakukan tugas yang diberikan, hal ini sering kali disebabkan karena kurangnya keyakinan sehingga keengganan untuk melakukan tugas lebih merupakan persoalan motivasi dibandingkan dengan keamanan. Oleh karena itu pemimpin dan pengikut selain komunikasi juga saling tukar menukar ide dalam melaksanakan tugas dan peranan pemimpin yang utama memberikan fasilitas dan berkomunikasi. .

4. Gaya Delegasi.

Menerapkan kepada bawahan yang memiliki tingkat kematangan tinggi karena bawahan mampu dan mau. Gaya ini melibatkan perilaku hubungan kerja dan tugas yang rendah, Dalam gaya ini pemimpin sering mendiskusikan masalah bersama bawahan sehingga tercapai kesepakatan, sehingga bawahan diperkenankan untuk melaksanakan sendiri dan memutuskannya tentang ihwal bagaimana, kapan dan dimana melakukan pekerjaan.

Bahwa gaya atau perilaku kepemimpinan dalam pelaksanaannya juga dipengaruhi oleh faktor eksternal, salah satunya adalah faktor budaya organisasi.

\section{Metodologi Penelitian \\ 3.1. Populasi.}

Populasi dalam penelitian ini sejumlah 212 orang pegawai tetap yang terdiri dari pegawai edukatif 146 orang dan pegawai administratif 66 orang. Menurut Sugiono (2009: 115) populasi adalah wilayah generalisasi yang terdiri atas obyek atau subyek yang mempunyai kualitas dan karakteristik tertentu yang ditetapkan oleh peneliti untuk dipelajari dan kemudian ditarik kesimpulannya,

\subsection{Sampel.}

Menurut Sugiono (2009: 116) sampel adalah bagian dari jumlah dan karakteristik yang dimiliki oleh populasi dan sampel yang diambil dari populasi harus betul-betul representatif (mewakili). Adapun sampel yang digunakan peneliti adalah sampel kuota, lebih lanjut Sugiono mengatakan bahwa sampling kuota adalah teknik untuk menentukan sampel dari populasi yang mempunyai ciri-ciri tertentu sampai jumlah yang diinginkan.

Adapun sampling dalam penelitian ini merupakan pejabat struktural yang mempunyai ciri-ciri: Direktur Program Pascasarjana/Dekan, Kepala Biro/Lembaga, Wakil Direktur Program Pascasarjana/Dekan, Kepala Pusat/Unit, Ketua Program Studi, Kepala Bidang, Kepala Laboratorium, Kasubid/Kasubag/Kasie, Koordinator Unit/Umum yang jumlahnya 91 responden ( $43 \%$ ) dimana secara kualitas dan kuantitas dapat memberi penilaian kuisioner serta mewakili seluruh pegawai.

\subsection{Variabel Penelitian}

Berdasarkan kerangka konsep dan hipotesis di atas terdapat 2 (dua) variabel yaitu : variable bebas (Independent) dengan simbol $\mathrm{X}$ dan variable terikat (dependent) dengan simbol $\mathrm{Y}$, sehingga dapat dirumuskan sebagai berikut :

1. Gaya Kepemimpinan (X1);

2. Budaya Organisasi (X2);

3. $\operatorname{Kinerja~(Y).~}$

Untuk mengukur variabel bebas (Independent) X1, X2 dan variabel terikat (dependent) Y peneliti menggunakan instrumen berupa angket yang disusun dengan skala Likert (Summated Rating Scale). Istijanto (2008: 81), skala likert adalah mengukur tingkat persetujuan atau ketidaksetujuan responden terhadap serangkaian pertanyaan yang mengukur suatu obyek yang biasanya memiliki 5 atau 7 kategori dari sangat setuju sampai sangat tidak setuju. Tanggapan kesetujuan dan ketidaksetujuan responden terhadap pertanyaan dan jawaban atas pertanyaan diklasifikasikan sebagai berikut :

1. Sangat tidak setuju mempunyai skor 1 ;

2. Tidak setuju mempunyai skor 2 ;

3. Ragu - ragu mempunyai skor 3 ;

4. Sutuju mempunyai skor 4 ;

5. Sangat setuju mempunyai skor 5 .

\subsection{Metode dan Teknik Pengumpulan Data.}

Menurut Sekaran (2006: 65) Metode pengumpulan data merupakan bagian integral dari desain penelitian yang meliputi Wawancara (tatap muka, telepon, media elektronik), kuesioner secara pribadi, 


\section{$17 \mid$ Suharyanto}

observasi individu. Sedangkan metode yang digunakan dalam penelitian ini adalah penelitian yang mengambil sampel dari populasi dengan menggunakan kuesioner yang berisi pernyataan tentang gaya kepemimpinan, budaya organisasi dan kinerja pegawai.

Sumber pengumpulan data dalam penelitian bersumber dari data yaitu :

(1) Data Primer adalah data yang diperoleh dari penyebaran kuesioner kepada responden;

(2) Data Sekunder adalah data yang diperoleh dari penelitian pada organisasi atau institusi, misal data administrasi maupun data lain yang mendukung.

\subsection{Uji Validitas}

Menurut Sugiyono (2009: 177-178) uji coba instrumen dicobakan pada sampel dimana populasi diambil dengan jumlah anggota sampel yang digunakan sekitar 30 orang dan selanjutnya diuji dengan analisis faktor yaitu dengan mengkorelasikan antar skor item instrumen dalam suatu faktor, dan mengkorelasikan skor faktor dengan skor total, serta bila korelasi tiap faktor tersebut positif dan besarnya $>0,3$ atau $\mathrm{p}<0,05$, maka faktor tersebut valid. Sedangkan Saroso (2008: 53) bahwa korelasi yang dibentuk berdasarkan teknik korelasi Product Moment dengan rumus :

Keterangan:

$$
r X Y=\frac{n \sum X Y-\left(\sum X\right)\left(\sum Y\right)}{\sqrt{\left\{n\left(\sum X^{2}\right)-\left(\sum X\right)^{2}\right\}\left\{n\left(\sum Y^{2}\right)-\left(\sum Y\right)^{2}\right\}}}
$$

$\mathrm{r}=$ koefisien korelasi Pearson validitas.

$\mathrm{x}=$ skor tanggapan responden setiap pernyataan,

$\mathrm{y}=$ skor total tanggapan responden seluruh pernyataan.

$\mathrm{n}=$ banyaknya subyek/jumlah responden.

\subsection{Analisis Faktor Konfirmatori.}

Menurut Yuhasril (2006: 5-6) menjelaskan bahwa analisis faktor-faktor mencoba menemukan hubungan (interrelationship)antar sejumlah variabel-variabel yang saling independen satu dengan yang lainnya, sehingga bisa dibuat satu atau beberapa kumpulan variabel yang lebih sedikit dari jumlah variabel awal. Tujuan analisis faktor adalah mengidentifikasi adanya hubungan antara variabel dengan melakukan uji korelasi. Prinsip utama analisis faktor adalah korelasi, maka asumsi yang terkait dengan korelasi adalah: besarnya korelasi antar independen variabel harus cukup kuat (diatas 0,5 ).

Lebih lanjut Santoso (Yuhasril 2006: 6) menjelaskan bahwa pengujian terhadap variabel-variabel yang telah ditentukan atau pengujian seluruh matrik karelasi antara variabel tersebut diukur dengan menggunakan metode test Kaiser-Meiyer-Olkin (KMO) and Barlett's test bahwa acuan untuk melakukan pengujian adalah korelasi yang cukup kuat antara independen variabel harus lebih besar dari 0,5 (>0,5).

\section{Analisa Data dan Pembahasan}

Universitas PGRI Adibuana Surabaya, merupakan salah satu perguruan tingi di Surabaya, yang berawal dari sebuah perguruan tinggi perjuangan untuk peningkatan mutu guru yang bernama IKIP PGRI Sarmidi Mangun Sarkoro (1971) dan berubah menjadi IKIP PGRI Jawa Timar (1975), selanjutnya berubah menjadi IKIP PGRI Surabaya (SK Mendidbud No 070/07/1985), dalam perkembangannya kemudian melakukan revitalisasi dan merger kelembagaan dengan STTL Adibuana Surabaya (SK Mendikbud RI No 47/D/O/1998, menjadi Universitas PGRI Adi Buana Surabaya) dengan alamat Kampus I. Jl. Ngagel Dadi IIIB/37 Surabaya dan Kampus II. Jl. Dukuh Menanggal XII/ 4 Surabaya.

Perubahan tersebut dalam rangka tuntutan relevansi, efektivitas dan efisiensi serta peluang dan tantangan global pengelolaan perguruan tinggi yang sehat di bawah naungan Perkumpulan Pembina Lembaga Pendidikan Perguruan Tinggi PGRI Surabaya (PPLP PT PGRI Surabaya).

Dalam rangka membantu program pemerintah menyiapkan sumber daya manusia yang handal Universitas PGRI Adi Buana Surabaya ikut serta memberikan sumbangsih khususnya dalam mencerdaskan kehidupan bangsa dengan jalan mendidik tenaga ahli, sarjana dan magíster melalui jenjang pendidikan Diploma, Strata-1 dan Strata-2.

\subsection{Karakteristik Responden.}

Bahwa responden dalam penelitian ini adalah pegawai Universitas PGRI Adi Buana Surabaya yang terdiri dari pegawai edukatif dan pegawai administratif berjumlah 91 orang yang merupakan pejabat struktural, lebih rinci terlihat dalam tabel sebagai berikut: 
Tabel 4.1

Klasifikasi Responden Unipa Surabaya

\begin{tabular}{|l|c|c|}
\hline \multicolumn{1}{|c|}{ Status } & Banyaknya & $\%$ \\
\hline Dekan, Direktur, Biro & 11 & 12 \\
\hline $\begin{array}{l}\text { Wadek, Wadir, Ka Pusat, Ka UPT, } \\
\text { Sekretaris }\end{array}$ & 21 & 23 \\
\hline Kaprodi, Kabid, Kabag & 33 & 36 \\
\hline Kalab, Kasubid, Kasubag, Kasie & 26 & 29 \\
\hline Jumlah & 91 & 100 \\
\hline
\end{tabular}

Dari jumlah 91 orang responden penelitian berjenis kelamin laki-laki dan perempuan, selengkapnya terlihat dalam tabel sebagai berikut:

\subsection{Karakteristik Data.}

Karakteristik data yang akan disajikan dari hasil penelitian ini adalah untuk memberikan suatu gambaran mengenai penyebaran data yang didapat di lapangan. Adapun data yang disajikan berupa data mentah yang diolah dengan menggunakan teknik statistik diskripsi.

Sebagaimana dalam lampiran 2 bahwa nilai jawaban dari 91 responden dicatat dalam urutan tidak teratur, dalam bahasan ini akan dipaparkan tentang distribusi frekuensi jawaban yang dikelompokkan sehingga akan memperoleh suatu gambaran yang lebih jelas mengenai jawaban respoden terhadap variabel-variabel yang diteliti.

\subsection{Variabel Gaya Kepemimpinan}

Distribusi frekuensi jawaban responden yang dikelompokkan berdasar indikator, dapat diketahui bahwa responden yang memberi penilaian baik terhadap Gaya kepemimpinan dalam tabel dan gambar sebagai berikut:

Tabel. 4.2

Frekuensi dan Persentase Jawaban Responden Terhadap Variabel Gaya kepemimpinan (X.1)

\begin{tabular}{|l|c|c|c|c|c|c|c|c|c|c|}
\hline \multirow{3}{*}{ Indikator } & \multicolumn{10}{|c|}{ Jawaban } \\
\cline { 2 - 13 } & \multicolumn{2}{|c|}{5} & \multicolumn{2}{|c|}{4} & \multicolumn{2}{|c|}{3} & \multicolumn{2}{|c|}{2} & \multicolumn{1}{|c|}{1} \\
\cline { 2 - 12 } & $\mathrm{F}$ & $\%$ & $\mathrm{~F}$ & $\%$ & $\mathrm{~F}$ & $\%$ & $\mathrm{~F}$ & $\%$ & $\mathrm{~F}$ & $\%$ \\
\hline x.1.1 & 84 & 18,50 & 195 & 42,95 & 65 & 14,32 & 83 & 18,28 & 27 & 5,95 \\
\hline x.1.2 & 144 & 31,65 & 249 & 54,73 & 48 & 10,55 & 11 & 2,42 & 3 & 0,16 \\
\hline x.1.3 & 123 & 27,03 & 202 & 44,40 & 77 & 16,92 & 41 & 9,01 & 12 & 2,64 \\
\hline x.1.4. & 107 & 23,52 & 218 & 47,91 & 82 & 18,02 & 35 & 7,69 & 13 & 2,86 \\
\hline
\end{tabular}

Bila dalam bentuk gambar sebagai berikut:

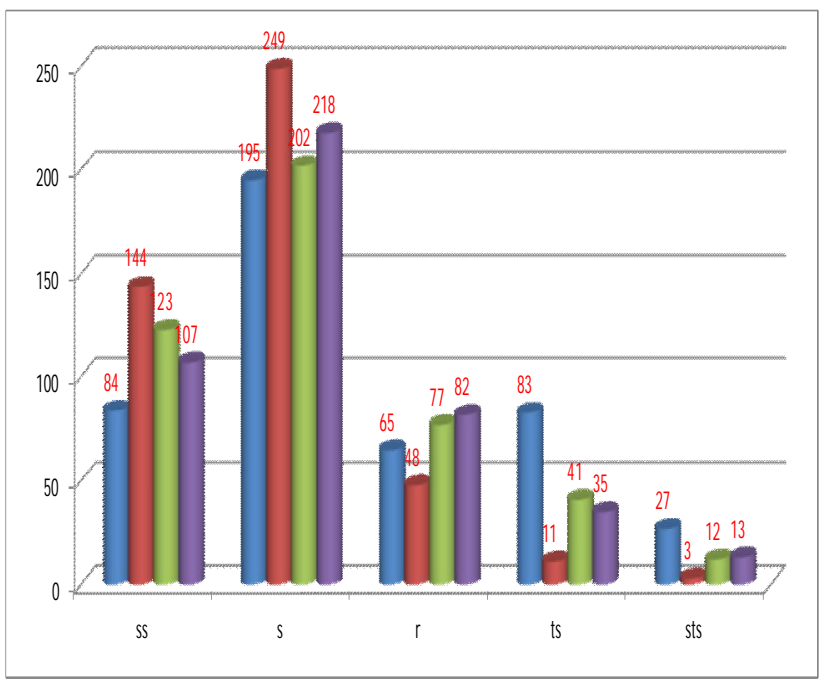

Gambar 4.1

Frekuensi Jawaban Responden Terhadap Variabel Gaya kepemimpinan (X.1) 


\section{9 |Suharyanto}

Dari tabel dan gambar tersebut diatas diuraikan bahwa variabel Gaya Kepemimpinan terdiri dari indikator sebagai berikut: (1) Indikator Instruksi menjawab sangat setuju 18,50\% dengan frekuensi 84 , setuju sebesar $42,95 \%$ dengan frekuensi 195 , ragu-ragu $14,32 \%$ dengan frekuensi 65 , tidak setuju $18,28 \%$ dengan frekuensi 83, dan sangat tidak setuju 5,95\% dengan frekuensi 27. (2) Indikator Konsultasi menjawab sangat setuju $31,65 \%$ dengan frekuensi 144 , setuju sebesar $54,73 \%$ dengan frekuensi 249 , ragu-ragu $10,55 \%$ dengan frekuensi 48, tidak setuju 2,42\% dengan frekuensi 11, dan sangat tidak setuju $0,16 \%$ dengan frekuensi 3, (3) Indikator Partisipasi menjawab sangat setuju 27,03\% dengan frekuensi123, setuju sebesar 44,40\% dengan frekuensi 202 , ragu-ragu $16,92 \%$ dengan frekuensi 77 , tidak setuju $9,01 \%$ dengan frekuensi 41 , dan sangat tidak setuju 2,64 \% dengan frekuensi 12 dan (4) Indikator Delegasi menjawab sangat setuju 23,52 \% dengan frekuensi107, setuju sebesar 47,91\% dengan frekuensi 218, ragu-ragu 18,02 \% dengan frekuensi 82 , tidak setuju 7,69\% dengan frekuensi 35, dan sangat tidak setuju 2,86 \% dengan frekuensi 13.

\subsection{Variabel Budaya Organisasi}

Distribusi frekuensi jawaban responden yang dikelompokkan berdasar indikator, dapat diketahui bahwa responden yang memberi penilaian baik dalam tabel dan gambar sebagai berikut:

\section{Tabel. 4.3}

Frekuensi dan Persentase Jawaban Responden Terhadap Variabel Budaya Organisasi (X.2)

\begin{tabular}{|l|c|c|c|c|c|c|c|c|c|c|}
\hline \multirow{3}{*}{ Indikator } & \multicolumn{910}{|c|}{ Jawaban } \\
\cline { 2 - 12 } & \multicolumn{2}{|c|}{5} & \multicolumn{2}{|c|}{4} & \multicolumn{2}{|c|}{3} & \multicolumn{2}{|c|}{2} & \multicolumn{1}{|c|}{1} \\
\cline { 2 - 12 } & $\mathrm{F}$ & $\%$ & $\mathrm{~F}$ & $\%$ & $\mathrm{~F}$ & $\%$ & $\mathrm{~F}$ & $\%$ & $\mathrm{~F}$ & $\%$ \\
\hline x.2.1 & 197 & 36,75 & 247 & 46,08 & 59 & 11 & 23 & 4,29 & 10 & 1,87 \\
\hline x.2.2 & 92 & 20,49 & 260 & 57,91 & 46 & 10,24 & 40 & 8,91 & 11 & 2,45 \\
\hline x.2.3 & 193 & 35,41 & 282 & 51,74 & 51 & 9,36 & 15 & 2,75 & 4 & 0,73 \\
\hline x.2.4. & 138 & 25,32 & 288 & 52,84 & 75 & 13,76 & 31 & 5,69 & 13 & 2,39 \\
\hline
\end{tabular}

Bila dalam bentuk gambar sebagai berikut:

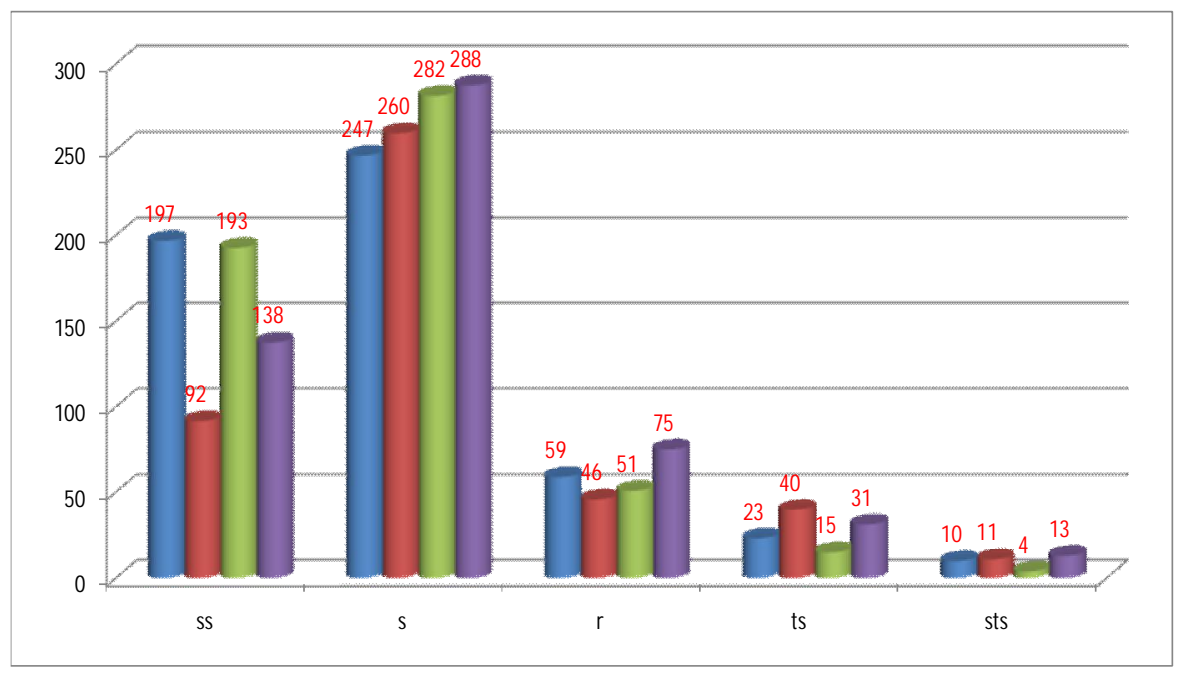

\section{Gambar 4.2 \\ Frekuensi Jawaban Responden Terhadap Variabel Budaya Organisasi (X.2)}

Dari tabel dan gambar tersebut diatas diuraikan bahwa variabel Budaya Organisasi terdiri dari indikator sebagai berikut: (1) Indikator Integritas menjawab sangat setuju 36,75\% dengan frekuensi 197, setuju sebesar 46,08 \% dengan frekuensi 247 , ragu-ragu $11 \%$ dengan frekuensi 59, tidak setuju 4,29 \% dengan frekuensi 23, dan sangat tidak setuju 1,87 \% dengan frekuensi 10, (2) Indikator Percaya pada rekan kerja menjawab sangat setuju 20,94 $\%$ dengan frekuensi 92 , setuju sebesar 57,91\% dengan frekuensi 260, ragu-ragu 10,24 \% dengan frekuensi 46, tidak setuju 8,91\% dengan frekuensi 40, dan sangat tidak setuju 2,45\% dengan frekuensi 11, (3) Indikator Peduli menjawab sangat setuju 35,41\% dengan frekuensi 193, setuju sebesar 51,74 \% dengan frekuensi 282 , ragu-ragu $9,36 \%$ dengan frekuensi 51 , tidak setuju $2,75 \%$ dengan frekuensi 15 , dan sangat tidak setuju $0,73 \%$ dengan frekuensi 4 dan (4) Indikator Profesional menjawab sangat setuju 25,32 \% dengan frekuensi 138, setuju sebesar 52,84 \% dengan frekuensi 288 , ragu-ragu $13,76 \%$ dengan frekuensi 75 , tidak setuju $5,69 \%$ dengan frekuensi 31, dan sangat tidak setuju 2,39\% dengan frekuensi 13. 


\subsection{Variabel Kinerja}

Distribusi frekuensi jawaban responden yang dikelompokkan berdasar indikator, dapat diketahui bahwa responden yang memberi penilaian baik dalam tabel dan gambar sebagai berikut:

Tabel. 4.4

Frekuensi dan Persentase Jawaban Responden terhadap Variabel Kinerja (Y)

\begin{tabular}{|l|c|c|c|c|c|c|c|c|c|c|}
\hline \multirow{3}{*}{ Indikator } & \multicolumn{10}{|c|}{ Jawaban } \\
\cline { 2 - 13 } & \multicolumn{2}{|c|}{5} & \multicolumn{2}{|c|}{4} & \multicolumn{2}{|c|}{3} & \multicolumn{2}{|c|}{2} & \multicolumn{1}{|c|}{1} \\
\cline { 2 - 12 } & $\mathrm{F}$ & $\%$ & $\mathrm{~F}$ & $\%$ & $\mathrm{~F}$ & $\%$ & $\mathrm{~F}$ & $\%$ & $\mathrm{~F}$ & $\%$ \\
\hline Y.1 & 78 & 12,30 & 379 & 59,78 & 122 & 19,24 & 49 & 7,73 & 6 & 0,95 \\
\hline Y.2 & 29 & 10,62 & 172 & 63 & 59 & 21,61 & 9 & 3,30 & 4 & 1,47 \\
\hline Y.3 & 79 & 28,84 & 240 & 63,32 & 47 & 12,40 & 11 & 2,90 & 2 & 0,53 \\
\hline Y.4. & 34 & 12,45 & 175 & 64,10 & 41 & 15,02 & 16 & 5,86 & 7 & 2,56 \\
\hline Y.5 & 57 & 15,70 & 288 & 62,81 & 53 & 14,60 & 20 & 5,51 & 5 & 1,38 \\
\hline
\end{tabular}

Bila dalam bentuk gambar sebagai berikut :

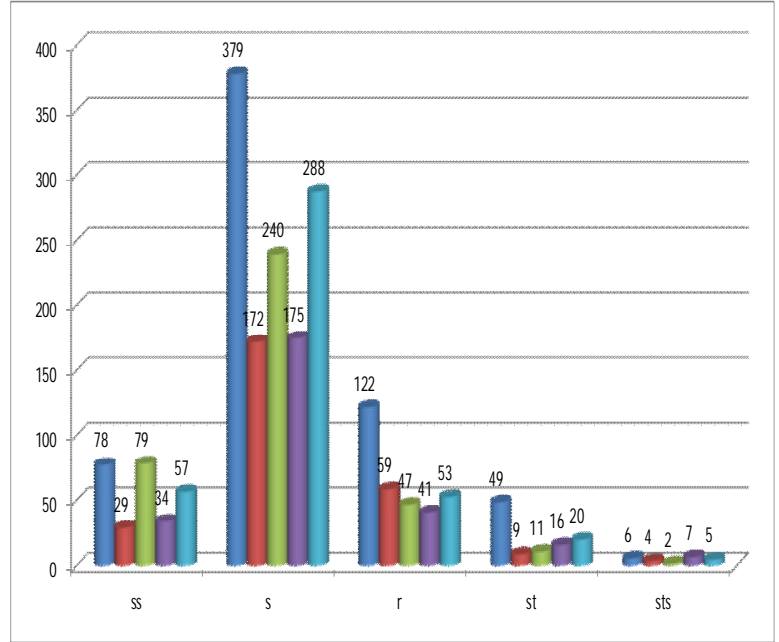

Gambar 4.3

Frekuensi Jawaban Responden Variabel Kinerja (Y)

Dari tabel dan gambar tersebut diatas diuraikan bahwa variabel Kinerja dengan indikator sebagai berikut: (1) Indikator Keterampilan Merencanakan menjawab sangat setuju 12,30\% dengan frekuensi 78, setuju sebesar $59,78 \%$ dengan frekuensi 379, ragu-ragu 19,24\% dengan frekuensi 122, tidak setuju 7,73\% dengan frekuensi 49, dan sangat tidak setuju 0,95\% dengan frekuensi 6. (2) Indikator Keterampilan Mengorganisasi menjawab sangat setuju 10,62 \% dengan frekuensi 29, setuju sebesar 59,78\% dengan frekuensi 172, ragu-ragu 19,24\% dengan frekuensi 59, tidak setuju 7,73\% dengan frekuensi 9, dan sangat tidak setuju 0,95\% dengan frekuensi 4. (3) Indikator Keterampilan Mengarahkan menjawab sangat setuju 28,84\% dengan frekuensi 79, setuju sebesar $63,32 \%$ dengan frekuensi 240, ragu-ragu 12,40\% dengan frekuensi 47, tidak setuju 2,90\% dengan frekuensi 11, dan sangat tidak setuju 0,53\% dengan frekuensi 2, (4) Indikator Keterampilan Mengendali menjawab sangat setuju 12,45 \% dengan frekuensi 34, setuju sebesar 64,10\% dengan frekuensi 175, ragu-ragu 15,02 \% dengan frekuensi 41 , tidak setuju 5,86\% dengan frekuensi 16, dan sangat tidak setuju 2,56\% dengan frekuensi 7 . dan (5) Indikator Menganalisa Masalah menjawab sangat setuju 15,70 \% dengan frekuensi 57, setuju sebesar 62,81 $\%$ dengan frekuensi 288, ragu-ragu 14,60\% dengan frekuensi 53, tidak setuju 5,51\% dengan frekuensi 20 , dan sangat tidak setuju $1,38 \%$ dengan frekuensi 5.

\subsection{Uji Linier.}

Berdasarkan hasil pengujian yang tertuang pada tabel 4.5 untuk mengetahui seberapa besar sumbangan variabel bebas secara simultan kepada variabel terikat dengan menggunakan F sebesar 40,068 dengah probabilitas sebesar $0,000<0,05$ dan $\mathrm{F}$ sebesar 54,358 dengan probabilitas sebesar $0,000<0,05$, dengan demikian hubungan variabel bebas dengan variabel terikat linier dan secara lengkap dapat dilihat dalam lampiran 8 . 
ANOVA Table

\begin{tabular}{|lll|r|r|}
\hline & & \multicolumn{1}{c|}{ F } & \multicolumn{1}{c|}{ Sig. } \\
\hline KINERJA * GAYA & Between Groups & (Combined) & 2,580 &, 001 \\
KEPEMIMPINAN & & Linearity & 40,068 &, 000 \\
& & Deviation from Linearity & 1,081 &, 389 \\
& Within Groups & & & \\
& Total & & 3,046 &, 000 \\
& Between Groups & (Combined) &, 000 \\
KINERJA * BUDAYA & & Linearity & 54,356 &, 093 \\
ORGANISASI & Deviation from Linearity & 1,491 & \\
& Within Groups & & & \\
& Total & & & \\
& &
\end{tabular}

\subsection{Uji Hipotesis Simultan.}

Tabel. 4.6

Model Summary ${ }^{\mathrm{b}}$

Hasil Uji Simultan

\begin{tabular}{|c|c|c|}
\hline R Square & Adjusted R Square & Std. Error of the Estimate \\
\hline, 428 &, 415 & 7,316 \\
\hline
\end{tabular}

Hasil pengujian model summary yang disajikan menunjukkan bahwa koefisien determinasi $\left(\mathrm{R}^{2}\right)$ dari variabel bebas yaitu Gaya Kepemimpinan dan Budaya Organisasi terhadap variabel terikat kinerja adalah 0,428. Hal ini berarti variabel prediktor memberikan sumbangan sebesar 42,8 \% terhadap variabel kriterium. Dengan demikian dapat dikatakan 57,2 \% dipengaruhi oleh variabel prediktor lainnya, dan secara lengkap dapat dilihat dalam lampiran 7.

Tabel 4.7

Hasil Uji Simultan

\begin{tabular}{|l|l|c|c|c|c|c|}
\hline \multicolumn{7}{|l|}{ ANOVA $^{\text {b }}$} \\
\hline \multicolumn{2}{|l|}{ Model } & Sum of Squares & df & Mean Square & F & Sig. \\
\hline \multirow{3}{*}{1} & Regression & 3523,483 & 2 & 1761,742 & 32,917 &, $000^{\text {a }}$ \\
\cline { 2 - 7 } & Residual & 4709,814 & 88 & 53,521 & & \\
\cline { 2 - 7 } & Total & 8233,297 & 90 & & & \\
\hline
\end{tabular} $\begin{aligned} & \text { a. Predictors: (Constant), BUDAYA ORGANISASI, GAYA KEPEMIMPINAN } \\
& \text { b. Dependent Variable: KINERJA }\end{aligned}$

\section{Coefficients $^{\mathrm{a}}$}

\begin{tabular}{|ll|c|c|c|c|c|}
\hline \multirow{2}{*}{ Model } & \multicolumn{2}{|c|}{$\begin{array}{c}\text { Unstandardized } \\
\text { Coefficients }\end{array}$} & $\begin{array}{c}\text { Standardized } \\
\text { Coefficients }\end{array}$ & & \\
\cline { 2 - 4 } & (Constant) & B & Std. Error & Beta & $\mathrm{t}$ & Sig. \\
\hline & GAYA & 6,987 & 9,369 & &, 746 &, 458 \\
& KEPEMIMPINAN &, 498 &, 136 &, 344 & 3,664 &, 000 \\
& BUDAYA ORGANISASI &, 381 &, 088 &, 407 & 4,338 &, 000 \\
\hline
\end{tabular}

a. Dependent Variable: KINERJA

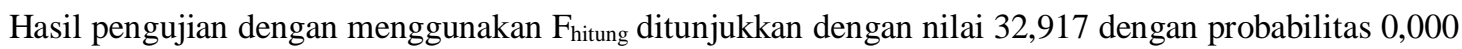
$<0,05$ berarti Ho ditolak Ha diterima artinya variable bebas secara simultan mempengaruhi variable terikat dan secara lengkap dapat dilihat dalam lampiran 7. Berdasarkan pada tabel 5.23 dapat dirumuskan sebuah model persamaan $\mathrm{Y}=6,987+0,498$ X.1 + 0,381 X.2.

Sehingga hipotesis secara simultan ada pengaruh yang signifikan antara Gaya Kepemimpinan Rektor dan Budaya Organisasi terhadap Kinerja pegawai di Universitas PGRI Adi Buana Surabaya.

\subsection{Uji Hipotesis Parsial.}


Uji hipotesis secara parsial dilakukan terhadap dua variabel bebas untuk menguji diterima atau tidak hipotesis nol, dan hipotesis parsial dilakukan apabila hasil uji signifikansi dengan uji t menunjukkan nilai lebih kecil dari 0,05 ( $\mathrm{p}<0,05)$.

Bahwa hipotesis Gaya kepemimpinan (X1) secara parsial berpengaruh terhadap kinerja pegawai dari hasil analisis yang menunjukan nilai $t_{\text {hitung }} 3,664$ sedangkan nilai $t_{\text {tabel }} 1,96$ dan nilai signifikansi $0,000<0,05$ berarti Ho ditolak Ha diterima sehingga variabel prediktor memberikan sumbangan sebesar 0,344 atau 34,4\% terhadap variabel kriterium dan dapat dikatakan 65,6\% dipengaruhi oleh variabel prediktor lainnya. Sehingga hipotesis secara parsial ada pengaruh yang signifikan antara Gaya Kepemimpinan Rektor terhadap Kinerja pegawai di Universitas PGRI Adi Buana Surabaya.

Bahwa hipotesis Budaya Organaisasi (X2) secara parsial berpengaruh terhadap kinerja pegawai dari hasil analisis yang menunjukan nilai $\mathrm{t}_{\text {hitung }} 4,338$ sedangkan nilai $\mathrm{t}_{\text {tabel }} 1,96$ dan nilai signifikansi $0,000<0,05$ berarti Ho ditolak Ha diterima sehingga variabel prediktor memberikan sumbangan sebesar 0,407 atau 40,7\% terhadap variabel kriterium dan dapat dikatakan 59,3\% dipengaruhi oleh variabel prediktor lainnya. Sehingga hipotesis secara parsial ada pengaruh yang signifikan antara Budaya Organisasi terhadap Kinerja pegawai di Universitas PGRI Adi Buana Surabaya.

\subsection{Pengaruh Gaya Kepemimpinan Rektor dan Budaya Organisasi secara Simultan terhadap Kinerja Pegawai Universitas PGRI Adi Buana Surabaya.}

Hasil pengujian model summary yang disajikan menunjukkan bahwa koefisien determinasi $\left(\mathrm{R}^{2}\right)$ dari variabel bebas yaitu Gaya Kepemimpinan dan Budaya Organisasi terhadap variabel terikat kinerja adalah 0,428. Hal ini berarti variabel prediktor memberikan sumbangan sebesar 42,8\% terhadap variabel kriterium, dengan demikian dapat dikatakan $57,2 \%$ dipengaruhi oleh variabel prediktor lainnya atau atau dengan $F_{\text {hitung }}$ ditunjukkan dengan nilai $0,000<0,05$ berarti Ho ditolak dan Ha diterima artinya variabel bebas secara simultan mempengaruhi variabel terikat. Demikian juga hasil penelitian dengan teknik statistik diskripsi bahwa Gaya Kepemimpinan Rektor dan Budaya Organisasi sebagian besar setuju .

Gaya Kepemimpinan menurut Hersey \& Balnchard (Pasolong 2010: 50) yang meliputi Instruksi, Konsultatif, Partisipasi , Delegasi dan Budaya Organisasi menurut Fuad (Heriyanti 2007: 41) yang meliputi Integritas, Percaya pada rekan kerja, Peduli, Profesional mampu secara signifikan meningkatkan Kinerja. Demikian juga menurut Donnelly (Edisi kedelapan: 5,8-9) kepemimpinan adalah suatu usaha menggunakan suatu gaya mempengaruhi dan tidak memaksa untuk memotivasi individu dalam mencapai tujuan

Implikasi adanya signifikasi antara Gaya kepemimpinan Rektor dan Budaya Organisasi secara simultan terhadap Kinerja adalah upaya untuk terus menerus meningkatkan kinerja melalui peningkatan Gaya kepemimpinan yang meliputi konsultasi, partisipasi dan delegasi, dan Budaya Organisasi yang meliputi integritas, percaya pada rekan kerja, peduli dan profesional terhadap kinerja Kinerja yang meliputi keterampilan merencanakan, keterampilan mengorganisasi, keterampilan mengarahkan, keterampilan mengendali dan menganalisa masalah.

\subsection{Pengaruh Gaya Kepemimpinan Rektor secara parsial terhadap Kinerja Pengawai Universitas PGRI Adi Buana Surabaya.}

Hasil pengujian signifikansi menunjukkan bahwa Gaya Kepemimpinan Rektor secara parsial berpengaruh

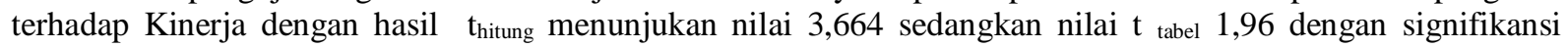
sebesar $0,000<0,05$ berarti Ho ditolak dan Ha diterima artinya variabel bebas secara parsial mempengaruhi variabel terikat serta memberi sumbangan sebesar 0,344 atau 34,4 \% terhadap variabel kriterium dan $65,6 \%$ dipengaruhi oleh variabel preditor lainnya.

Menurut Timpe (1999: 123) bahwa gaya kepemimpinan yang ideal adalah menggunakan semua gaya yang ada sebaik mungkin, hal ini berarti bahwa situasilah yang mungkin menentukan gaya apa yang sesuai, Sedangkan menurut Gibson, Ivancevich, dan Donnelley (dalam Sudarmadi, 2007: 18), memberikan pengertian kepemimpinan (leadership) sebagai suatu upaya penggunaan jenis pengaruh bukan paksaan untuk memotivasi orang-orang mencapai tujuan tertentu. Dengan kata lain seorang leader adalah seseorang yang mempunyai daya untuk menarik orang lain dengan tanpa paksaan agar mereka secara bersama-sama mewujudkan visinya.

Implikasi adanya signifikasi antara Gaya kepemimpinan Rektor secara parsial terhadap Kinerja dikarenakan adanya Gaya Kepemimpinan (1) Konsultasi melalui membimbing dan mengarahkan, memberi pujian, penyampaian ide atau gagasan. (2) Partisipasi melalui komunikasi, memperhatikan keluhan-keluhan, menerima saran, membantu menyelesaikan pekerjaan. (3) Delegasi melalui mempercayakan pekerjaan, memberi pekerjaan sesuai dengan kompetensi. Sehingga Kinerja dengan indikator (1) Keterampilan Merencanakan melalui program jangka pendek dan panjang, merumuskan rencana kerja, mampu mengantisipasi masalah yang mungkin terjadi ke arah pencapaian tujuan lembaga. (2) Keterampilan Mengorganisasi melalui penempatan sumber daya manusia sesuai dengan keahlian, mampu meminimalkan ketidakefisienan dalam operasi kerja. (3) Keterampilan Mengarahkan melalui membimbing dan mengarahkan bawahan dalam kegiatan kerja, memotivasi, komunikasi interpersonal. (4) Keterampilan Mengendali melalui memberi informasi kemajuan kerja bawahan 


\section{Suharyanto}

tanpa menyinggung perasaan, memastikan bahwa tujuan yang ditetapkan telah tercapai. (5) Menganalisa Masalah melalui penetapan hubungan timbal balik, pengambilan keputusan yang praktis, membedakan masalah berat dan ringan, menetapkan anggaran dengan kegiatan yang akan dilakukan. Dan akhirnya pegawai akan memiliki apresiasi tinggi yang bertujuan untuk memberikan hasil kerja yang terbaik.

\subsection{Pengaruh Budaya Organisasi secara parsial terhadap Kinerja Pengawai Universitas PGRI Adi Buana Surabaya.}

Hasil pengujian signifikansi menunjukkan bahwa Budaya Organisasi (X2) secara parsial berpengaruh terhadap Kinerja Pegawai dari hasil analisis yang menunjukan nilai $t_{\text {hitung }} 4,338$, sedangkan nilai $t_{\text {tabel }} 1,96$ dan nilai signifikansi $0,000<0,05$ berarti Ho ditolak Ha diterima sehingga variabel prediktor memberikan sumbangan sebesar 40,7 \% terhadap variabel kriterium dan dapat dikatakan 59,3\% dipengaruhi oleh variabel prediktor lainnya,

Hal tersebut dapat diartikan bahwa berjalannya budaya organisasi berjalan dengan baik, sehingga memberi gambaran bahwa para pegawai mempunyai rasa memiliki terhadap organisasi dan bersepakat untuk memegang teguh norma yang berlaku dalam mencapai tujuan bersama.

Koesmono (2005) dalam penelitiannya mengatakan bahwa secara langsung budaya organisasi berpengaruh terhadap kinerja sebesar 0,506, Demikian pula hasil penelitian Saleh Sarpin (Sukadiono 2007: 66) yang menyarankan bahwa organisasi untuk dapat memelihara dan meningkatkan budaya organisasinya dalam rangka perbaikan kinerja yang terus menerus.

Implikasi adanya signifikasi antara Budaya Organisasi secara parsial terhadap Kinerja dikarenakan adaya Budaya Organisasi dengan indikator (1) Integritas yang berfungsi sebagai alat penyatuan beragam sifat, karakter, bakat dan kemampuan melalui pelatihan atau studi lanjut, penghargaan terhadap hasil kerja. (2) Percaya pada rekan kerja dikarenakan dalam menjalankan tugasnya kerjasama dan saling keterkaitan yang ditekankan hal ini disebabkan bahwa pekerjaan tersebut dilakukan dalam suatu tim melalui antar rekan kerja saling menghargai pekerjaanya, percaya terhadap kemampuan rekan kerja. (3) Peduli yang merupakan perekat sosial terhadap onggota organisasi untuk terciptanya iklim kerja yang kondusif melalui kepedulian terhadap pegawai yang mengalami musibah, tenggang rasa terhadap kegiatan keberagaman agama, kepedulian terhadap lingkungan sekitar kampus dan lembaga sosial, budaya sopan santun berkembang dengan baik. (4) Profesional yaitu memberikan arah dan memperkuat perilaku untuk mengendalikan pelaku organisasi agar melaksanakan tugas dan tanggung jawab secara efektif dan efisien guna mencapai tujuan dan sasaran organisasi yang telah disepakati bersama melalui memisahkan urusan kerja dengan urusan pribadi, mempertahankan standar prestasi kerja, disiplin dalam melaksanakan tugas.

Dan Budaya sebagai identitas sebuah organisasi selayaknya terus dikembangkan kearah yang makin baik. Sosialisasi budaya dengan komunikasi yang baik akan mampu menciptakan suatu kekuatan organisasi sehingga kinerja makin meningkat. Peningkatan kinerja akan berpengaruh positif terhadap komitmen pegawai dalam memajukan organisasi serta mengembangkan kemampuan pribadi, sehingga suatu organisasi yang selalu memperhatikan budaya organisasi dalam melaksanakan kegiatannya bertujuan untuk menilai kinerja pegawai.

\section{Kesimpulan}

Berdasarkan analisis dan pembahasan hasil penelitian tentang Pengaruh gaya kepemimpinan Rektor dan Budaya Organisasi terhadap Kinerja Pegawai Universitas PGRI Adi Buana Surabaya, maka disimpulkan sebagai berikut :

1. Terdapat pengaruh signifikan antara Gaya kepemimpinan Rektor dan Budaya Organisasi secara simultan terhadap Kinerja Pegawai Universitas PGRI Adi Buana Surabaya. Hal ini ditunjukkan dengan analisis Faktor Konfirmatori ( $>0,5)$ sebagai berikut: (1) Gaya Kepemimpinan Rektor dengan indikator Gaya Konsultasi sebesar 0,763, Gaya partisipasi sebesar 0,865, dan Gaya Delegasi sebesar 0,843. (2) Budaya Organisasi dengan indikator Integritas sebesar 0,810, Percaya pada rekan kerja sebesar 0,843, Peduli sebesar 0,773 dan Profesional sebesar 0,941. dan (3) Kinerja dengan indikator Keterampilan Merencanakan sebesar 0,790, Keterampilan Mengorganisasi sebesar 0,811, Keterampilan Mengarahkan sebesar 0,838, Keterampilan Mengendali sebesar 0,808, Menganalisis masalah sebesar 0,831. Dan uji summary $\left(\mathrm{R}^{2}\right)$ memberi sumbangan

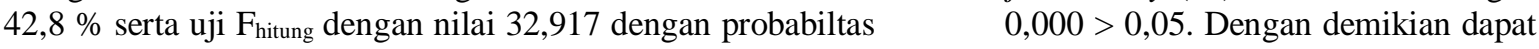
diartikan semakin baik Gaya Kepemimpinan Rektor dan Budaya Organisasi yang diterapkan oleh pimpinan dan pegawai, maka kinerja pegawai semakin baik pula.

2. Terdapat pengaruh signifikan antara Gaya kepemimpinan Rektor secara parsial terhadap Kinerja Pegawai Universitas PGRI Adi Buana Surabaya. Hal ini dapat diartikan bahwa semakin baik Gaya Kepemimpinan Rektor yang dijalankan, maka kinerja pegawai semakin meningkat. Hal ini berdasarkan hasil thitung menunjukan nilai 3,664 sedangkan nilai $t$ tabel 1,96 dengan signifikansi sebesar $0,000<0,05$ berarti Ho ditolak dan Ha diterima artinya variabel bebas secara parsial mempengaruhi variabel terikat serta memberi sumbangan sebesar 0,344 atau 34,4\%

3. Terdapat pengaruh signifikan antara Budaya Organisasi secara parsial terhadap Kinerja Pegawai Universitas PGRI Adi Buana Surabaya. Hal ini dapat diartikan bahwa semakin baik Budaya Organisasi yang diterapkan 
oleh pimpinan dan pegawai, maka kinerja pegawai semakin meningkat Hal ini berdasarkan hasil $t_{\text {hitung }}$ menunjukan nilai 4,338 sedangkan nilai $t_{\text {tabel }} 1,96$ dengan signifikansi sebesar $0,000<0,05$ berarti Ho ditolak dan Ha diterima artinya variabel bebas secara parsial mempengaruhi variabel terikat serta memberi sumbangan sebesar 0,407 atau $40,7 \%$

\section{Daftar Pustaka}

Brahmasari, Ayu, Ida., Suprayetno, Agus. 2008. Pengaruh Motivasi Kerja, Kepemimpinan dan Budaya Organisasi terhadap kepuasan Kerja Karyawan serta dampaknya terhadap kinerja Perusahaan, Jurnal Manajemen dan Kewirausahaan, Vol.10, No.2.

Dharma, Surya. 2010. Manajemen Kinerja. Yogyakarta: Pustaka Pelajar.

Gujarati, N, Damodar. 2006. Dasar-Dasar Ekonometrika. Edisi ketiga jilid 2. Jakarta: Erlangga.

Gunarso, Gatot. 2009. Pengaruh Budaya organisasi, Kepemimpinan dan Kualitas Sumber Daya Manusia terhadap Kinerja Pegawai BLK Surabaya. Universitas Narotama Surabaya, tidak dipublikasikan.

Heriyanti, Dewita. 2007. Analisis Pengaruh Budaya Organisasi, Kepuasan Kerja dan Gaya Kepemimpinan terhaadap Kinerja karyawan dengan komitmen Organisasi sebagai variabel Intervening PT.PLN (Persero) Semarang. Semarang: Universitas Diponegoro.

Istijanto. 2008. Riset Sumber Daya manusia. Jakarta: Gramedia Pustaka utama.

Koesmono, Temon. 2005. Pengaruh Budaya Organisasi terhadap Motivasi dan Kepuasan Kinerja Karyawan pada sub sektor Industri pengolahan kayu skala menengah di Jawa Timur, Jurnal Manajemen \& Kewirausahaan, Vol.7, No.2. Surabaya: Universitas Kristen Petra.

Mariam, Rani. 2009. Pengaruh Gaya kepemimpinan dan Budaya Organisasi terhadaap Kinerja karyawan melalui kepuasan Kerjam Karyawan sebagai variable Intervening kantor Pusat PT Asuransi Jiwa Indonesia (Persero). Semarang: Universitas Diponegoro.

Nawawi, Hadari. 2006. Kepemimpinan Mengefektifkan Organisasi. Yogyakarta: Gajah Mada University Press.

Pasolong, Harbani. 2010. Kepemimpinan Birokrasi. Bandung: Alfabeta.

Riani, Laksmi, Asri. 2011. Budaya Organisasi. Yogyakarta: Graha Ilmu.

Saroso, Edi. 2010. Peran Gaya Kepemimpinan terhadap Motivasi staf dalam upaya meningkatkan kinerja staf Studi pada Unit Pelaksana Teknis Bina Marga Surabaya (tidak dipublikasikan). Surabaya: Universitas Narotama.

Santoso, Purbayu, Budi. 2002. Analisis Statistik dengan Microsoft Excel \& SPSS. Yogyakarta: ANDI Offset. Sekaran, Uma. 2006. Research Methods For Business. Buku 2. Jakarta: Salemba empat.

Simanjuntak, J, Payaman. 2005. Manajemen Evaluasi Kinerja. Yogyakarta: Lembaga Penerbit Fakultas Ekonomi UI.

Sugiyono.2009. Metode Penelitian Bisnis. Bandung: Alfabeta.

2011. Statistik untuk Penelitian. Bandung: Alfabeta.

Sukadiono. 2007. Pengaruh Kepemimninon dan Budaya Organisasi terhadap Kinerja Karyawan Fakultas Ilmu kesehatan Universil rammadiyah Surabaya (tidak dipublikasikan). Surabaya: Universitas Narotama. 66

Sutrisno, Edy. 2010. Budaya Organisası. Jakarta: Kencana Prenada Media Group.

Sudarmadi. 2007. Analisis Pengaruh Budaya Organisasi dan Gaya Kepemimpinan terhadap Kepuasan Kerja dan Kinerja Karyawan Universitas Semarang. Semarang: Universitas Diponegoro.

Toha, Miftah. 2009. Perilaku Organisasi Konsep Dasar dan Aplikasinya. Jakarta: PT Raja Grafindo. 
Tika, Pabundu, Moh. 2008. Budaya Organisasi dan Peningkatan Kinerja Perusahaan. Jakarta: Bumi Aksara.

Timpe, A, Dale. 1999. Seri Manajemen Sumber Daya Manusia 2. Kepemimpinan. Jakarta: PT Elex Media Komputindo.

Wahjono, Imam, Sentot. 2010. Perilaku Organisasi. Yogyakarta: Graha Ilmu.

Yuhasril. 2006. Analisis Faktor-Faktor yang mempengaruhi Struktur Modal Perusahaan Farmasi yang telah Go Publik di Bursa Efek Jakarta. bulletin Penelitian. No. 9 